\title{
Effects of dried water melon and sweet orange peel (dwmop) meal mixture on the haematological and serum indices of growing rabbits
}

\author{
Oluwafemi R.A ${ }^{1}$, Omokore E.A ${ }^{2}$, Alagbe J.O ${ }^{3}$ \\ ${ }^{1,2,3}$ Department of Animal Science, University of Abuja, Nigeria \\ Email: emmanuelomokore@hotmail.com
}

\begin{abstract}
The objective of the present study was to evaluate effects of dried water melon and sweet orange peel (dwmop) meal mixture on some haematological and serum indices of growing rabbits. A total of sixty rabbits 7-8 weeks old with an average weight of $630-645 \mathrm{~g}$ were randomly divided into five (5) dietary treatments with three (3) replicates and four rabbits per replicate in a Completely Randomized Design (CRD). The dietary treatments include a control diet with no DWMOP in (T1), T2 (5.0\% DWMOP), T3 (10.0 \% DWMOP), T4 (15.0\% DWMOP) and T5 (20.0\% DWMOP) respectively. Feed and water were offered ad libitum throughout the experiment which lasted for 12 weeks. Data obtained were used to evaluate the haematological parameters (PCV, RBC, Hb, MCV, $\mathrm{MCH}, \mathrm{MCHC}, \mathrm{WBC}$ and its differentials ), some serum biochemical indices (Albumin, globulin, total protein, creatinine, bilirubin, AST and ALT). All the haematological parameters measured were significantly $(\mathrm{P}<0.05)$ different among the treatments. Total protein, bilirubin and creatinine values were not significantly $(\mathrm{P}>0.05)$ influenced by DWMOP, however, glucose level and activities of ALP and AST were significantly $(\mathrm{P}<0.05)$ affected by DWMOP. It was concluded that inclusion of DWMOP at $20 \%$ in the diet of rabbits does not have any deleterious effect on the health status of the animal.
\end{abstract}

Keywords: Growing rabbits; Agro industrial by-products; haematology; serum indices.

\section{INTRODUCTION}

Citrus plants belonging to the family Rutaceae which include fruits such as orange, lime, lemon, sour orange and grapefruit appear as a well known promising source of multiple beneficial nutrients for human beings. Processing of citrus by-products potentially represents a rich source of phenolic compounds and dietary fibre, owing to the large amount of peel produced. These citrus fruit residues, which are generally discarded as waste in the environment, can be referred to as potential vitamin sources. Due to their low cost and easy availability, such wastes are capable of offering significant low-cost nutritional dietary supplements. The utilization of these bioactive rich citrus residues can provide an efficient, inexpensive, and environment-friendly platform for production. Shortage of national feed resource particularly in developing countries has necessitated the investigation of novel sources of feedstuff. For instance, dried sweet orange peel (DSOP) is exactly a potential source of some valuable nutrients for poultry feed as a source of natural antioxidants. DSOP is also a good source of calcium, but very low in phosphorus and carotene. Based on some observed data, dried and/or pelleted citrus pulp is one of the most desirable energy feeds and can be considered in feeding programs as a feed with high digestible nutrient content. Arthington and Pate (2001) estimated that the waste from feeding wet citrus pulp could be as high as $30 \%$. Although it is very palatable to grazing animals, it is typically uneconomical to feed wet pulp because of the increased cost of shipping (Kunkle et al., 2001).

Rabbit production for fast meat yield is, however, affected by inadequate and high cost of feed ingredients brought about mainly by the stiff competition between man and monogastric animals for grain and oilseeds (Agunbiade et al., 2002). The favourable attributes of the rabbit which has projected it as a target species for curtailing protein malnutrition cannot be realized because of the high cost of conventional feedstuffs. Animal nutritionists in collaboration with livestock producers have thus intensified the search for less costly and readily available alternative feed materials. It is observed that the increasing mechanization of crop farming in developing economies has led to a rise in the tonnage of agro-allied byproducts most of which lies waste. One of such wastes could emanate from the citrus, a major fruit of subtropical region (Rice and Rice, 1987).

Sweet orange (Citrus sinensis) production in Nigeria is significant, with heavy direct consumption due primarily to few and small capacity processing industries to convert the fruit to juice, concentrate and canned fruit. Nigeria produces $3 \%$ of fresh citrus in the world and Africa produces 3,741,000 ton of different varieties of citrus fruits of which Nigeria contributes 3,240,000 ton (FAO, 2004).

Both Watermelon peel and sweet orange peel meal are waste products not competed for by man. They are readily available and not sold, hence would help to reduce the cost of production. They generally litter the environment and Volume 3, Issue X, October $2020 \mid 244$ 
thereby constitute environmental nuisance in some locations. The unavailability and expensive nature of cereals (maize and sorghum) stemming directly from its use as staple human food as well as major feed ingredients in Nigeria creates the problem of rising feed cost. This unprecedented increase in the cost of feed has made the price of some products beyond the reach of the average Nigerian (Ahaotu et al., 2011). Sweet orange fruit meal has been observed to be a source of caloric and protein comparable with maize (Aggey, 2003). The utilization and incorporation of both dried watermelon peel and sweet orange peel meal into rabbit feed will go a long way in increasing rabbit production and utilization.

Therefore this experiment was carried out to examine the effects of dried water melon and sweet orange peel (DWMOP) meal mixture on the haematological and serum indices of growing rabbits.

\section{MATERIALS AND METHODS}

\section{Experimental Site}

The experiment was carried out at the University of Abuja Teaching and Research Farm, Animal Science Section, Main Campus, along Airport Road, Gwagwalada, Abuja-Nigeria, located between latitude $8^{0} 57^{\mathrm{I}}$ and $8^{0} 55^{\mathrm{I}} \mathrm{N}$ and longitude $7^{0} 05^{\mathrm{I}}$ and $7^{0} 06^{\mathrm{I}} \mathrm{E}$.

\section{Source of test material and preparation}

Freshly cut water melon peel and sweet orange peel (Citrus sinensis) were collected from the popular Orange Market, Mararaba/Nyanyan, a suburb market between Nasarawa state and the FCT Abuja. The samples were thoroughly washed under running water to remove sand particles after which they were sliced to smaller pieces using a home choice knife, and sun-dried. The pulp of the watermelon was carefully scraped off to obtain the rind. The samples were oven dried at $60-70^{\circ} \mathrm{C}$ for two days, pulverized separately to obtain the water melon rind meal and orange peel meal and stored into an air tight container for further analysis.

Pre-experimental operations

Prior to the commencement of the experiment the rabbit hutches were properly cleaned and disinfected, electrical fittings were put in place and foot bath was placed to ensure proper biosecurity.

Animals and their management

A total of sixty rabbits of 7-8 weeks old with an average weight of $630-645 \mathrm{~g}$ were sourced from the National Animal Production Research Institute (NAPRI) Zaria, Kaduna State and used for the experiment. Animals were weighed before the commencement of the experiment to obtain the initial body weight, housed in an all wired hutch and randomly divided into five (5) dietary treatments with three (3) replicates and four rabbits per replicate in a Completely Randomized Design (CRD). Animals were allowed two weeks of acclimatization, feeders and drinkers were made available in each hutch. The drinkers were washed regularly before fresh water was frequently served ad-libitum and other prophylactic treatment was administered throughout the experimental period which lasted for 12 weeks.

Formulation of experimental diets

The watermelon peel and the orange peel were mixed together at 50/50 to obtain (DWMOP). The test material was mixed with other ingredients to form five experimental diets. DWSOP was partially used to replace maize at $0 \%, 5$ $\%, 10 \%, 15 \%$ and $20 \%$ respectively.

Measured parameters

Feed intake $(\mathrm{g} /$ rabbit $)=$ Feed offered $(\mathrm{g})$ - Leftover $(\mathrm{g})$

Mortality was recorded as it occurs.

\section{Blood analysis}

On the $10^{\text {th }}$ week of the experiment, blood samples were collected from the vein of three randomly selected rabbits per treatment. Blood was collected in sterile vials in the morning time between 07:00 am and 10:00 am hours before the rabbits get access to feed. The bleeding procedure was the method described by Schalm et al. (1975). The blood samples were analyzed for some haematological and serum biochemical parameters; blood samples for haematology were collected into bottles containing Ethylene Diamine Tetra Acetate (EDTA). The haematological parameters such as Pack cell volume (PCV), Red blood cell (RBC), White blood cell (WBC), Haemoglobin concentration $(\mathrm{Hb})$ and absolute counts of lymphocytes and monocytes were computed according to the method of Jain (1986).

Blood samples that were meant for serum chemistry were collected into bottles free of any anticoagulant. It was centrifuged for 10 minutes and the serum was separated and analyzed. Albumin, globulin and serum total protein were determined by Biuret reactions (Bush, 1975) and cholesterol (Roschianet al., 1974). ALT and AST were determined colourimetrically (Reitman and Frankel, 1957). Total glucose and cholesterol levels were determined as described by (Toro and Ackermann, 1975).

Phytochemical analysis of DWMOP

Proximate analysis of experimental diet was determined using methods described by AOAC (2000). Phytochemical screening of DWMOP was analyzed according to methods outlined by Harbone (1973); Trease and Evans (1983).

\section{Statistical analysis}

All data were subjected to one -way analysis of variance (ANOVA) using SPSS (18.0) and significant means were 
separated using Duncan multiple range tests (Duncan, 1955). Significant was declared if $\mathrm{P} \leq 0.05$.

Table 1 Chemical composition of experimental diet

\begin{tabular}{lccccc}
\hline Materials & $\mathrm{T} 1$ & $\mathrm{~T} 2$ & $\mathrm{~T} 3$ & $\mathrm{~T} 4$ & $\mathrm{~T} 5$ \\
\hline Maize & 55.20 & 52.44 & 50.20 & 42.67 & 34.14 \\
Wheat offal & 30.00 & 30.00 & 30.00 & 30.00 & 30.00 \\
DWMOP & 0.00 & 2.76 & 5.24 & 7.53 & 8.53 \\
Soya meal & 9.74 & 10.74 & 10.74 & 10.74 & 10.74 \\
Groundnut cake & 1.26 & 5.26 & 5.26 & 5.26 & 5.26 \\
Limestone & 1.00 & 1.00 & 1.00 & 1.00 & 1.00 \\
Bone meal & 2.00 & 2.00 & 2.00 & 2.00 & 2.00 \\
Lysine & 0.15 & 0.15 & 0.15 & 0.15 & 0.15 \\
Methionine & 0.15 & 0.15 & 0.15 & 0.15 & 0.15 \\
Premix & 0.25 & 0.25 & 0.25 & 0.25 & 0.25 \\
Salt & 0.25 & 0.25 & 0.25 & 0.25 & 0.25 \\
Total & 100.0 & 100.0 & 100.0 & 100.0 & 100.0 \\
Calculated analysis & & & & \\
Crude protein $(\%)$ & 16.43 & 16.35 & 16.22 & 16.10 & 16.02 \\
Crude fibre $(\%)$ & 10.62 & 10.47 & 10.30 & 10.10 & 10.00 \\
Ether extract $(\%)$ & 3.52 & 3.49 & 3.43 & 3.38 & 3.27 \\
Energy (Kcal/kg) & 2732.1 & 2715.0 & 2700.1 & 2698.9 & 2690.0 \\
\hline
\end{tabular}

Table 2 Phytochemical composition of DWMOP

\begin{tabular}{lcc}
\hline Parameters & Composition $(\%)$ & *Recommended range $(\%)$ \\
\hline Alkaloids & 1.88 & 3.50 \\
Flavonoids & 5.47 & 36.11 \\
Phenols & 4.09 & 20.01 \\
Saponins & 2.04 & 7.02 \\
Tannins & 1.00 & 11.50 \\
Phyatate & 0.75 & - \\
\hline
\end{tabular}

*Alagbe et al. (2020)

Table 3 Haematological parameters of growing rabbits fed different levels of DWMOP

\begin{tabular}{|c|c|c|c|c|c|c|c|}
\hline Parameters & $\mathrm{T} 1$ & $\mathrm{~T} 2$ & T3 & $\mathrm{T} 4$ & T5 & SEM & $*$ N.R \\
\hline $\operatorname{PCV}(\%)$ & $29.78^{\mathrm{c}}$ & $31.32^{\mathrm{b}}$ & $38.45^{\mathrm{b}}$ & $44.31^{\mathrm{a}}$ & $45.72^{\mathrm{a}}$ & 0.43 & $33.0-47.0$ \\
\hline $\mathrm{RBC}\left(\mathrm{x} 10^{6} / \mathrm{ul}\right)$ & $3.00^{\mathrm{c}}$ & $4.41^{\mathrm{c}}$ & $5.00^{\mathrm{b}}$ & $6.20^{\mathrm{a}}$ & $6.55^{\mathrm{a}}$ & 0.13 & $3.00-8.09$ \\
\hline $\mathrm{Hb}(\mathrm{g} / \mathrm{dl})$ & $9.09^{c}$ & $10.44^{\mathrm{b}}$ & $10.92^{\mathrm{b}}$ & $13.12^{\mathrm{a}}$ & $13.88^{\mathrm{a}}$ & 0.40 & $10.0-17.5$ \\
\hline $\operatorname{MCV}(\mathrm{fl})$ & $90.44^{\mathrm{a}}$ & $69.80^{\mathrm{b}}$ & $69.64^{\mathrm{b}}$ & $65.31^{\mathrm{b}}$ & $68.94^{\mathrm{b}}$ & 1.88 & $59.0-101.5$ \\
\hline $\mathrm{MCH}(\mathrm{pg})$ & $32.22^{\mathrm{a}}$ & $29.83^{b}$ & $29.22^{\mathrm{b}}$ & $27.40^{\mathrm{c}}$ & $22.71^{\mathrm{c}}$ & 0.31 & $15.0-32.0$ \\
\hline $\mathrm{MCHC}(\%)$ & $48.67^{\mathrm{a}}$ & $48.16^{\mathrm{a}}$ & $48.81^{\mathrm{a}}$ & $40.22^{\mathrm{b}}$ & $40.37^{\mathrm{b}}$ & 0.43 & $25.0-50.00$ \\
\hline WBC (x103/ul) & $9.19^{c}$ & $9.79^{c}$ & $10.02^{\mathrm{b}}$ & $17.50^{\mathrm{a}}$ & $17.46^{\mathrm{a}}$ & 0.22 & $5.80-20.10$ \\
\hline Lympho. (\%) & $48.00^{\mathrm{c}}$ & $59.63^{\mathrm{b}}$ & $59.90^{\mathrm{b}}$ & $59.44^{\mathrm{b}}$ & $61.00^{\mathrm{a}}$ & 1.71 & - \\
\hline Monocytes (\%) & $1.28^{c}$ & $1.22^{\mathrm{c}}$ & $1.50^{\mathrm{b}}$ & $1.88^{\mathrm{a}}$ & $1.94^{\mathrm{a}}$ & 0.08 & - \\
\hline
\end{tabular}

Means in the same row with different superscripts are significantly different $(P<0.05)$

PCV: Pack Cell Volume; RBC: Red Blood Cell; Hb: Haemoglobin; MCV: Mean Corpuscular Volume; MCH: Mean Corpuscular Haemoglobin; MCHC: Mean Corpuscular Haemoglobin Concentration; WBC: White Blood Cell; N.R: Normal range.

Table 4 Serum biochemical indices of growing rabbits fed different levels of DWMOP

\begin{tabular}{|c|c|c|c|c|c|c|c|}
\hline Parameters & $\mathrm{T} 1$ & $\mathrm{~T} 2$ & T3 & $\mathrm{T} 4$ & T5 & SEM & Range \\
\hline Albumin $(\mathrm{g} / \mathrm{dl})$ & 3.02 & 3.21 & 3.20 & 3.20 & 3.21 & 0.22 & $3.30-4.7$ \\
\hline Globulin $(\mathrm{g} / \mathrm{dl})$ & 3.00 & 3.40 & 3.31 & 3.36 & 3.37 & 0.07 & $3.10-5.3$ \\
\hline $\mathrm{Tp}(\mathrm{g} / \mathrm{dl})$ & 6.02 & 6.61 & 6.51 & 6.56 & 6.58 & 0.12 & $4.5-7.9$ \\
\hline Glu. (Mmol/L) & $5.33^{c}$ & $5.05^{\mathrm{b}}$ & $7.22^{\mathrm{b}}$ & $7.60^{\mathrm{b}}$ & $8.30^{\mathrm{a}}$ & 0.46 & $3.83-8.32$ \\
\hline Creat. (Mmol/L) & 0.40 & 0.41 & 0.42 & 0.40 & 0.43 & 0.01 & $0.20-0.66$ \\
\hline $\mathrm{Db}(\mu \mathrm{mol} / \mathrm{L})$ & 0.73 & 0.70 & 0.72 & 0.70 & 0.81 & 0.03 & $0.85-0.71$ \\
\hline $\mathrm{Tb}(\mu \mathrm{mol} / \mathrm{L})$ & 3.41 & 3.09 & 3.00 & 3.47 & 3.41 & 0.12 & $1.71-5.13$ \\
\hline $\operatorname{AST}(\mathrm{iu} / \mathrm{L})$ & $14.91^{\mathrm{a}}$ & $10.22^{\mathrm{b}}$ & $10.05^{\mathrm{b}}$ & $8.44^{\mathrm{c}}$ & $7.93^{c}$ & 0.04 & $7.00-19.0$ \\
\hline ALP (iu/L) & $21.10^{\mathrm{a}}$ & $17.82^{\mathrm{b}}$ & $13.07^{\mathrm{c}}$ & $13.02^{\mathrm{c}}$ & $13.05^{\mathrm{c}}$ & 0.10 & $13.0-26.0$ \\
\hline
\end{tabular}


Means in the same row with different superscripts are significantly different $(P<0.05)$

AST: Aspartate aminotransferase; ALP: alkaline phosphate; Glu: Glucose; Creat: Creatinine; Tb: Total bilirubin; Db: Direct bilirubin; SEM: Standard error of the mean.

\section{RESULTS}

\section{Phytochemical composition of DWMOP meal mixture}

Table 2 reveals the phytochemical composition of DWMOP. The phytochemical components contained 1.88 $\%, 5.47 \%, 4.09 \%, 1.00 \%$ and $0.75 \%$ for alkaloids, flavonoids, phenols, tannins and saponin respectively.

Hematological parameters of weaner rabbits fed graded levels of DWMOP meal mixture.

Table 3 shows the hematological parameters of weaner rabbits fed graded levels of DWMOP meal mixture. The values for PVC are $29.78 \%, 31.32 \%, 38.45 \%, 44.3 \%$ and $45.72 \%$ for treatments 1, 2, 3, 4 and 5 respectively, while those of RBC are 3.00, 4.41, 5.00, 6.20, 6.55 respectively. Values obtained for MCV are 90.44, 69.80, 69.64, 65.31 and 68.94 for treatments $1,2,3,4$ and 5 respectively. The data obtained for Haemoglobin are 9.09, 10.44, $10.92,13.12$ and 13.88 for treatments $1,2,3,4$ and 5 respectively. Likewise, values obtained for $\mathrm{MCH}$ are 32.22 , 29.83, 29.22, 27.40 and 22.71 for treatment 1, 2, 3, 4 and 5 respectively. MCHC has values of 48.67\%, 48.16\%, $48.81 \%, 40.22 \%$ and $40.37 \%$ for treatment 1, 2, 3, 4 and 5 respectively. The values obtained for WBC are 9.19, 9.79, 10.02, 17.50 and 17.46 for treatments $1,2,3,4$ and 5 respectively. The values for Lymphocytes $(\%)$ are $48.00 \%, 59.63 \%, 59.90 \%, 59.44 \%$ and $61.00 \%$ for treatment $1,2,3,4$ and 5 respectively.

\section{Serum biochemical indices of weaner rabbits fed graded levels of DWMOP meal mixture}

Table 4 shows the serum biochemical indices of weaner rabbits fed graded levels of DWMOP meal mixture. The values recorded for Albumin are 30.02, 32.10, 32.11, 32.0 and 32.13 for treatments 1, 2, 3, 4 and 5 respectively. Values for globulin are 30.0, 34.00, 33.13, 33.06 and 33.71 for treatments 1, 2, 3, 4 and 5 respectively. The values for Total Protein are 60.02, 66.10, 65.24, 65.06 and 65.80 for treatment 1, 2, 3, 4 and 5 respectively. The values recorded for Glucose $(\mathrm{Mmol} / \mathrm{L})$ are 5.33, 5.05, 7.22, 7.60, 8.30 while those of Creatinine $(\mathrm{Mmol} / \mathrm{L})$ are 0.40 , $0.41,0.42,0.40$ and 0.43 for treatments $1,2,3,4$ and 5 respectively. The values recorded for Direct Bilirubin $(\mu \mathrm{mol} / \mathrm{L})$ are $0.73,0.70,0.72,0.70$ and 0.81 , Total Bilirubin $(\mu \mathrm{mol} / \mathrm{L}) 3.41,3.09,3.00,3.47$ and 3.40 for treatments $1,2,3,4$ and 5 respectively.

\section{DISCUSSION}

Phytochemicals are secondary metabolites or bioactive chemicals found in plants. Secondary metabolites of plants play a vital role as a defense mechanism against attack by microorganisms (Cowan, 1999; Dreosti, 2000; Alagbe et al., 2020). Phytochemical results (Alkaloids (1.88\%), Flavonoids (10.47\%), Phenols (16.08), Tannins $(1.09 \%)$ and Saponins $(3.88 \%)$ of DWMP in this current study were consistent with the permissible range reported by Alagbe et al. (2020). According to Bako et al. (2005); Omokore and Alagbe (2019); Oluwafemi et al. (2020), phytochemicals vary in distribution within the plant parts as well as in their occurrence within the plant species and have also been reported to reduce the risk of some diseases due to their protective and therapeutic roles (Adesanya and Sofowora, 1983).

Phenols are found in many plants and they function as antioxidants, free radicals scavengers (Cespedes et al, 2008; Chanda and Dave, 2009), anti-inflammatory, anti-ageing and anti-carcinogen (Han et al, 2007). Phenol is an erythrocyte membrane modifier (Adesanya and Sofowora, 1983). Saponin performs antimicrobial and antiinflammatory roles (Hassan et al., 2012). Saponin plays a significant role in maintaining blood cholesterol levels (Cheeke, 2000). According to Adisa et al. (2010) and Chinwe et al. (2015), tannins are known to possess antibacterial, anti-inflammatory, anti-parasitic, anti-cancer, anti-viral and antioxidant activity, and Flavonoids have protective effects including anti-inflammatory, antioxidant, antiviral, antidiabetic and anti-carcinogenic properties (Bashir et al. 2020; Alagbe, 2019). Alkaloids are heterogeneous group of naturally occurring compounds found in the leaves, roots and barks of some plants, they are found to have antimicrobial properties due to their ability to intercalate DNA of microorganisms (Kasolo et al., 2010; Shittu et al., 2020).

Haematological studies represent a useful process in the diagnosis of many diseases as well as investigation of the extent of damage to the blood (Onyeyili et al., 1991), they are good indicators of the physiological status of animals (Khan and Zafar, 2005). Haematological variables and protein levels of the blood of livestock are known to be positively correlated with protein quality (Adeyeni et al., 2000; Alagbe et al., 2019). Results on the blood haematological parameters of weaner rabbits fed different graded levels of DWMOP meal presented in Table 3 showed PCV of between $29.78 \%-45.72 \%$, haemoglobin values of $9.09-13.88$ (g/dl) while RBC values are 3.00 -6.55 . The PCV values fall within the normal ranges of 30-60\% previously reported by (Flecknell 2000). All the haematological parameters obtained in this study showed that they were significantly $(\mathrm{P}<0.05)$ influenced by the dietary inclusion of DWMOP meal. The PCV, Hb, RBC, MCV and WBC values obtained slightly increased from diet 1 to 5, though not at a significant level. The parameters observed in this study were within the normal ranges for rabbits reported by (Mituka and Rawnsley, 1997). According to Olabanji et al. (2007) the values for all the parameters fall within the normal range established by Mitruka and Rawnsley (1977) for rabbits. Post Graduate Committee on Veterinary Sciences (PGCVS) (1990) reported a standard WBC range of $2.5-12.5\left(\mathrm{x} 10^{3} / \mathrm{mm}^{3}\right)$. Reilly (1993) opined that normal range of values for WBC indicated that the animals were healthy because decrease 
in number of WBC below the normal range is an indication of allergic conditions, anaphylactic shock and certain parasitism. The WBC and its differentials increased from diet 1 to 5, a higher WBC value implies an increase in antibody level and high resistance to diseases (Soetan et al., 2013; Oluwafemi and Alagbe, 2019).

Togun and Oseni (2005) reported that haematological analysis is useful in disease diagnosis and nutritional stress. It also provides the opportunity to clinically investigate the presence of several metabolites and other constituents in the body (Doyle 2006; Alagbe and Oluwafemi, 2019). Nutrition and dietary contents affect the blood profile of healthy animals (Yeong 1999, Abass et al., 2012). Esonu et al., (2012) reported that haematological parameters like haemoglobin concentration, white blood cell counts, red blood cell counts are dictating the level of oxygen in the blood. Blood parameters are excellent medium for measurement of potential biomarkers, because its collection is relatively non-invasive, and it shows an enormous range of physiological process in the body at any given time. Changes in blood profile can be due to disease and nutritional stress Afolabi et al., (2001), age and sex (Cheeke and Nobert 2000) and breed.

Table 4 shows the serum biochemistry of weaner rabbits fed graded levels of DWMOP meal. The results revealed that the values obtained for total protein in this study were not significantly $(P>0.05)$ among the treatments. The total protein values obtained is $6.2-6.58(\mathrm{~g} / \mathrm{dl})$ which fall within the normal ranges of 5.40-7.50 (g/dl) previously reported by (Medirabbit, 2011), this shows that the protein quality in the diet is able to support the growth in tissue and cell rebuild after stress (Alagbe, 2017). Glucose and activities Aspartate aminotransferace (AST) values and alkaline phosphate (ALP) were significantly $(P<0.05)$ affected by DWMOP. However, all values fall within the normal ranges reported by Ozkan et al. (2012) on the normal biochemical parameters of New Zealand white rabbits. This therefore implies that DWMOP meal has no toxic chemicals that could compromise the activity of the liver of the animals. Creatinine and bilirubin were not significantly $(P>0.05)$ influenced by DWMOP, this is an indication that the kidney is functioning properly.

\section{CONCLUSION}

It was concluded that DWMOP contains several bioactive chemicals and other nutrient necessary for the proper development of the body. Therefore, dried water melon peel and sweet orange peel meal mixtures could be included in the diet of weaner rabbits up to $20 \%$ without any deleterious effect on the health and general performance of rabbits without causing any pathological abnormalities in their blood profile.

\section{REFERENCES}

1. A.O.A.C. (2000). Association of Official Analytical Chemists. Official Methods of Analysis Washington, USA, 19: 69-77.

2. Alagbe, J.O (2019). Proximate, mineral and phytochemical analysis of Piliostigma thonningii stems bark and roots. International Journal of Biological, Physical and Chemical Studies, 1(1): 1-7.

3. Afolabi, K. D., Akinsoyinii, A. O., Olajide, R. and Akinleye, S. B. (2010). Haematological parameters of the Nigerian local grower chickens fed varying dietary levels of palm kernel cake. Proc. of the 35th Annual Conf. of the Nig. Soc. for Anim. Prod., 247.

4. Adenkola, A. Y. and Dunotoye, L. A. (2004). Haematological study during pre-partum periods in brown Savanna does in Zaria, Nigeria. Annual Conf. of the Agric. Soc. of Nig. 538-540.

5. Bamishaiye, E., Muhammad, N. and Bamishaiye, O. (2009). Haematological parameters of albino rats fed on tiger nuts (Cyperuss esculentus) tuber oil meat based diet. The Internet Journal of Nutrition and Wellness, 10(1):2-6.

6. Alagbe, J.O. (2019). Haematology, serum biochemistry, relative organ weight and bacteria count of broiler chicken given different levels of Luffa aegyptiaca leaf extracts. International Journal of Advanced Biological and Biomedical Research. 7(4):382-392.

7. Bamgbose, A. M., S. D. Ogungbenro, E. E. Obasohan, M. B. Aruna and I.T. Oteko (2004). Replacement value of maize offal/cashew nut for maize in broiler diets. Annual Conference of Nigerian Society for Animal Production, 1: 399-402.

8. Omokore, E.O and Alagbe, J.O. (2019). Efficacy of dried Phyllantus amarus leaf meal as an herbal feed additive on the growth performance, haematology and serum biochemistry of growing rabbits. International Journal of Academic Research and Development. 4(3): 97-104.

9. Musa, Bashir., Alagbe, J.O., Adegbite Motunrade Betty, Omokore, E.A. (2020). Growth performance, caeca microbial population and immune response of broiler chicks fed aqueous extract of Balanites aegyptiaca and Alchornea cordifolia stem bark mixture. United Journal for Research and Technology, 2(2):13-21.

10. Alagbe, J.O., Agubosi, O.C.P., Ajagbe, A.D, Shittu, M.D and Akintayo Balogun, O.M (2020). Performance, haematology and serum biochemical parameters of growing grass cutters fed Phyllantus amarus and Piliostigma thonningii leaf meal mixture as partial replacement for Soya bean meal. United International Journal for Research and Technology, 2(1): 14-23.

11. Bush, B. M. (1991). Interpretation of Laboratory Results for Small Animal Clinical. Blackwell Scientific Volume 3, Issue X, October $2020 \mid 248$ 
publication London, UK.

12. Shittu, M.D., Adejumo, D.O., Ewuola, E.O., Alaba, O., Alagbe, J.O and Ojebiyi, O.O. (2020). Gut morphometric characteristic and ecological response of broiler starter fed varied levels of protein. Asian Journal of Animal Science, 14(1):33-39.

13. Alagbe, J.O. (2019). Performance and haemato-biochemical parameters of weaner rabbits fed diets supplemented with dried water melon (rind) meal. Journal of Dairy and Veterinary Sciences. 8(4):001-007.

14. Alagbe, J.O and Oluwafemi, R.A. (2019). Performance and haematological parameters of broiler chicks gives different levels of dried lemon grass (Cymbopogon citratus) and garlic (Allium sativum) extract. Research in: Agricultural and Veterinary Sciences. 3(2): 102 - 111.

15. Cespedes, C.L., M. El- Hafidi, N. Pavon and J. Alarcon (2008). Antioxidant and cardioprotective activities of Phenolic extract from fruits of Chilean blackberry (Aristotelia chilensis) of Maqui. Food Chemistry. 107:820-829.

16. Chanda, S. and R. Dave (2009). In vitro models for antioxidant activity evaluation and some medicinal plants processing antioxidant properties. An overview. African Journal of Microbiology Research, 3:981-996.

17. Cheeke, P.R., P.J., Manning, D. H. Ringler and C.E. Newcomber.(1994) Rabbit Feeding and Nutrition. The Biology of the Laboratory Rabbit. 2:321-340.

18. Alagbe, J.O and Oluwafemi, R.A. (2019). Hematology and serum biochemical indices of growing rabbits fed diet supplemented with different levels of Indigofera zollingeriana leaf meal. Progress in Chemical and Biochemical Research. 2(4): 170-177.

19. Oluwafemi, R.A., Isiaka Olawale and Alagbe, J.O. (2020). Recent trends in the utilization of medicinal plants as growth promoters in poultry nutrition- A review. Research in: Agricultural and Veterinary Sciences. 4(1): 5-11.

20. Alagbe, J.O. (2017). Effect of feeding different levels of Tridax procumbens meal on the performance, carcass characteristics and blood profile of growing cockerels. Scholarly Journal of Agricultural Science. 7(1):20-26.

21. Chineke, C. A., Ologun, A. G. and Ikeobi, C. O. N. (2006). Haematological parameters in rabbit breeds and crosses in humid tropics. Pakistan Journal of Biological Sciences, 9:2102-2106.

22. Cho, J.M., Seddon, B., Roser, E.C., Willet and S.E. Hankinson (2004). Prospective study of intake of fruits, vegetables, vitamins and carotenoids and risk of age, 6:883-892.

23. Del Rio, D., Rodriguez- Mateos, A, Spenser, J.P.E., Tognolini, M. and Borges, G. Crozier (2013). Dietary phenolics in human health: structures, bioavailability and evidence of protective effects against chronic diseases. Antioxidants and Redox Signaling, 18:1818-1892.

24. Dreosti, (2000). Recommended dietary intake levels for phytochemicals. Feasible or Fanciful. Asia Pacific Journal of Clinical Nutrition, 9:119-122.

25. Duncan, D.B. (1955). Multiple Range and Multiple F-Test Biometrics 11: 1-42.

26. Alagbe, J.O. (2017). Nutrient evaluation of sweet orange (Citrus sinensis) fruit peel as a replacement for maize in the diets of weaner grass cutters. Scholarly Journal of Agricultural Science. 6(8):277-282.

27. Egbuonu, A.C.C. (2015). Assessment of some anti-nutrient properties of water melon rind and seeds. Research Journal of Environmental Sciences. 9: 225-232.

28. Esonu, B. O., Emenalom, O. O., Udedibie, A. B. I., Berbert, U., Ekpor, C. F., Okoli, E. C. and Iheukwumere, F. C. (2001). Performance and chemistry of weaner pigs fed raw mucuna bean (Velvet bean) meal. Trop. Anim. Prod. Invest., 4:49-54.

29. Ewuola, E. O., Sokunbi, A. O., Alaba, O., Omotoso, J. O. and Omoniyi, A. B. (2010). Haematology and serum biochemistry of weaned rabbits fed dietary prebiotics and probiotics. Annual Conf. of the Nig. Soc. for Anim. Prod., 147.

30. Fila, W.A, Ifam, E.H., Johnson, J.T., Odey, M.O, and Effiong, E.E. (2013). Comparative proximate compositions of watermelon Citrullus Lanatus, Squash cucurbita pepo'l and Rambutan, Nephelium Lappaceum. International Journal of Science and Technology, 2(1): 81-88.

31. Gwana, A.M., Bako, M.M., Bagudu, B.Y., Sadiq, A.B. and Abdullahi, M.M. (2014). Determinations of phytochemical, vitamin, mineral and proximate compositions of varieties of water melon seeds cultivated in Borno State, north-Eastern Nigeria. International Journal of Nutrition and food Sciences, 3(4): 238-245.

32. Hafiza, M.A., B. Parreen, R. Ahmad and K. Hamid (2002). Phytochemical and antifungal screening of Medicago sativa and Zinnia elegan. Online Journal of Biological Sciences, Vol-2, pp-130-132.

33. Hassan, H.S., Sule, M.I., Musa, A.M and Musa, K.Y (2012). Anti-inflammatory activities of crude saponin extracts from five Nigerian medicinal plants. African Journal of Traditional, Complementary and Alternative Medicines, 9:250 -255.

34. Ibrahim H, Hassan M.R., Abdu, S.B., Chidinma, F., Aliyu, Z.I., (2018). Blood biochemical profile and carcass characteristics of weaner rabbits fed varying levels of Gamba grass (Andropogon gayanus Kunth) forage. Nigeria Journal of Animal Science. 20 (4): 522- 560.

35. Ikram, U.H., Sikander A., Qadeer M.A., and Javed I. (2002). Citric acid fermentation by mutant strain of Aspergillus niger GCMC-7, using molasses based medium. Electronic Journal of Biotechnology, 5(2):717- 3458 . 
36. Iheukwumere, F. C., Herbert, U., Iloeje, M. U. and Onyekwere, M. (2007). Physiological response of West African Dwarf does to progesterone injections: Haematology and serum biochemistry. Annual Conf. of Nig. Sco. For Anim. Prod., 79-82.

37. Ipinloju, Z.A. (2000). Introduction to Poultry Animal Production. 28(1):20. Production in Nigeria, Bodija, Oyo state.

38. Jenkins, J.R. (1999). Feeding recommendations for the horse rabbit: Veterinary Clinics of North America: Exotic Animal Practice. 2:143. W.B. Saunders Company, Philadelphia.

39. Johnson, J.T., Iwang, E.U., Hemen, J.T., Odey, M.O. and Effiong, E.E. (2012). Evaluation of anti-nutrients contents of watermelon Citrullus lanatus. Annals of Biological Research 3(11): 5145-5150.

40. Keyvan, D.H.J., Diamen, D., L., Raimo, H. (2007). Chemical composition and antioxidative activity of moldavian balm (Dracocephalum moldavica L.) extracts. LWT-Food Science and Technology, 40:16551663.

41. Kasolo, J.N., Gabriel, S., Bimenya, L.O, Joseph, O and Ogwal-Okeng, J.W (2010). Phytochemical and uses of Moringa leaves in Ugandan rural coomunities. Journal of Medicinal Plants Research, 4(9):753757.

42. Kumar, V and Amit, K (2010). Dietary role of phytate and phytase. Retrieved October 6, 2019 from http//www.scribd.com

43. McDonald P., Edwards R.A., Greenhalgh J.F.D., Morgan C.A. (2002). Animal Nutrition (6thEd.). Pearson Education (Singapore) Press Ltd New Delhi, India. 693.

44. Megias M.D., Martinez Teruela A., Gallego J.A., Nuñez J.M. (1993). Chemical changes during the ensiling of orange peel. Animal Feed Science and Technology, 1993;43 (3-4):269-274.

45. Mitruka, B. M. and Rawnsley, H. M. (1977). Clinical, biochemical and haematological reference values in normal and experimental animals. Masson Publishing, USA, Inc., 83:134-135.

46. Neal R.W. and Stovers F.A. (1999). Rabbit management in the tropics production, processing, utilization, marketing, economics, research and future prospects. Living books series, UK, 20-24.

47. NRC (National Research Council). (1991). Micro- livestock little known small ruminants with a promising economic future. National Academy Press, Washington D.C .Pp 192-282.

48. Olatunji, A.K., Alagbe, J.O., Hammed. M.A. (2016). Effects of varying level of Moringa olifera on the performance of weaner rabbits. International Journal of Science and Research. 5: 6-7.

49. Olayinka, B.U., Etejere, E.O. (2018). Proximate and chemical composition of (Citrullus lanatus) and Cucumber. International Food Research Journal. 25(3): 1060-1066.

50. Oluremi, B.E. (2008). The role of vitamins and other nutrients in broiler diets. Tropical AnimalHealth Production, 11:199-202.

51. Perkins-veazie, P., Collins, J.K. (2004). Flesh quality and lycopene stability of fresh-cut watermelon. Postharvest Biology and technology, 31:159-166.

52. Stevenson, D.E., and Hurst, R.D. (2007). Polyphenolic Photochemical-Just antioxidants or much more? Cellular and Molecular Life Sciences, 64(22):2900-2916.

53. Serres, H. (1992). Manual of Pig Production in the Tropics. CAB International, Wellington. 14-

54. Togun, V. A., Oseni, B. S. A., Ogundipe, J. A., Arewa, T. R., Hammed, A. A., Ajonijebu, D. C., Oyeniran, A., Nwosisi, I. and Mustapha, F. (2007). Effects of chronic lead administration on the haematological parameters of rabbit - a preliminary study. Conf. of the Agric. Soc. of Nig., 41:341342.

55. Unigwe, C.R., Balogun, F.A., Okorafor, U.P., Odah, S.I., Abonyi, F.O., Olona, J.F. (2016). Effect of neem leaf (Azadirachta indica) meal on growth performance and hematology of rabbits. World Scientific News. 55:51-62.

56. Williams, R.J. and Spencer, J.P. (2012). Flavonoids, cognition and dementia: actions, mechanisms and potential therapeutic utility of Alzheimer disease. Free Radical Biology and Medicine, 2(52):35-45. 